some of the questions that could have been used to better link the detailed, and extremely rich empirical material with the theoretical issues to which they relate.

On the other hand, researchers interested in idiographic research will find this work a masterpiece. The book shows the complexity (not only in terms of logistics) of carrying out research in rural settings, and the resulting deep involvement between researchers and their "subjects." Interestingly, under these circumstances, dinners, accidental talks by the porch and even the tacit negotiation around the organization of the fridge become important instances or points of observation. Moreover, this intensely-done participatory observation led to magnificent moments of meta-analysis, as the authors constantly delved into self-reflection about their role as researchers, their partiality as observers, and into how the "subjects" perceive their work and intentions. Finally, also of great interest in the book is the collaborative nature of the work. Despite the fact that the two authors wrote separate chapters, they produced considerably harmonious narratives, which is admirable given their difference in age, gender, life experience, and the fact that they are father and daughter.

Simone Bohn York University

\title{
Ted McCoy, Hard Time: Reforming the Penitentiary in Nineteenth-Century Canada (Edmonton: AU Press, 2012). 339 pp. \$29.95 Paperback.
}

The creation of the Canadian penitentiary system was a reflection of its time, embodying issues of religion, morality, architecture and - above all else - labour. From its very start, the Canadian prison was firmly rooted in the industrial capitalist economy. This is the central theme of Ted McCoy's Hard Time, and he ably demonstrates the extent to which this reality not only dominated nineteenth-century approaches to the problem of crime and punishment, but also how it came to determine virtually every aspect of the prison experience.

Beginning with the 1835 establishment of Kingston Penitentiary, the new penal regime was infused with humanitarian ideals and visionary rhetoric. However, advocates were ultimately less influenced by the English reform models of John Howard and his contemporaries than by US examples. Indeed, before Kingston Penitentiary even received its first inmates, Upper Canadian authorities were already waxing enthusiastic about New York's Auburn state prison - which ultimately served as their template. Unlike rival Pennsylvania state prison, whose regime of absolute solitary confinement had the unfortunate tendency to drive inmates insane, the Auburn plan was also cheaper to construct and maintain. More to the point, Auburn held out the promise - the virtual guarantee, colonial officials were ensured - of turning a tidy profit. Offenders 
would not only be rehabilitated, but "reintegrated into the world of capital through productivity and self sufficiency." In such a system, McCoy observes, the prison sentence became little more than "a unit of economic exchange" (270). Prisons followed the factory model, their discipline and routine premised on the hope that inmates would experience redemption through labour. The final products of this redemptive toil were expected to make the prison financially self-sufficient in a system where material production was inseparable from institutional ideology (28).

Such dreams were not to be. Success was elusive, as workers outside the prison walls objected (usually successfully) to inmate labour, not only heavily subsidised by the state, but which also tended to degrade their own status as "free" workers. Contracts for prison industries were difficult to procure and never profitable, so meanwhile the majority of inmates were set to work expanding the prison structure itself, in a "seemingly never-ending construction project" (41). In only fifteen years, the system collapsed under the weight of its own contradictions; the Brown Commission of 1849 revealing a scandalous litany of managerial incompetence, embezzlement, and shockingly inhumane punishments (47). It could hardly have been otherwise. Harsh discipline was the only way to motivate inmates to work as hard as was necessary to turn a profit, but it was an unsuitable foundation for individual moral reform.

Rather than jettison the penitentiary as a failed experiment, the postConfederation federal state repeated it four more times before century's end: at Montreal's St. Vincent de Paul Penitentiary; Dorchester in New Brunswick; New Westminster in British Columbia; and Winnipeg's Stoney Mountain Prison.

Reforms were little more than cosmetic: a tinkering of inspectors and wardens, each with ill-defined and often conflicting powers, either at odds with one another, or simply ineffective. The result, McCoy shows, was a penal regime sceptical of new advances in criminology, and slow to implement the "Croftonian" reforms embraced in England, which emphasised earned remission (parole), improved inmate classification, and nominal pay for prisoners' labour (81-2).

Attempting simultaneously to reform convicts, to punish them, and to train them as part of a disciplined workforce, failure was all but assured in a system still unsure of its own purpose.

It is this labour theory of punishment that is the focus of McCoy's first three chapters, and together they provide a solid history of the institutions themselves, and the ideology that drove them. Much of this material will already be familiar to the student of historical criminology, but the book's strength lies in links McCoy draws between the Canadian experience and larger international trends - a feature which would make this volume a valuable teaching resource. Having shown the centrality of labour to the prison regime, McCoy then demonstrates how it penetrated every aspect of penitentiary life, from race relations to inmate health, and beyond. It is in these subsequent chapters that Hard Time truly impresses. 
In his chapter on prison medicine, McCoy offers a comprehensive examination of institutional medical practices, convincingly connecting prisoners' experiences of ill-health to their position in the labour regime, and highlighting the often-resulting poor treatment. Penitentiary staff's awareness of mental health issues lagged behind outside medical knowledge, and resulted in inappropriate inmates being incarcerated. The mentally ill, elderly, and other non-working inmates could not participate in the reformatory program, and existed in a "grey area ... only in the shadows of labour" (183). Institutional medical personnel were deeply implicated in keeping inmates part of the productive industrial discipline, but widespread poor health among inmates frequently resulted in a conflation of disease and idleness with working class immorality that the medical discourse was only marginally successful in addressing.

The experience of imprisonment was similarly mediated by racial imperatives. High incarceration rates for Indigenous peoples reflected the prison's role in countering their political challenge in Western Canada, subduing this unruly and threatening cohort and conscripting them into a new world of regularised work discipline. The shocking death rate among Indigenous inmates eventually served to merely reinforce dominant views concerning their supposed inferior racial type (197).

The problem of corruption within the prison is also shown as an ongoing concern, and this study does not neglect those entrusted with maintaining institutional discipline and order. The lives of guards, in particular, were often as regimented and curtailed as those of the inmates. In a system so rigid, and with its mission so poorly defined, major corruption among only a few officials could severely disrupt the discipline of the entire prison, again throwing into stark contrast the gulf between reformist rhetoric and the day-to-day reality behind the walls (177). By the end of the nineteenth century, the abuses chronicled in 1849 were repeating themselves throughout the entire system.

McCoy concludes his study by posing a number of provocative questions, and in contemplating them, there appears little room for optimism. The project to both punish and reform criminals within a single institution has, above all, been a two hundred year story of failure. It is not enough to ask "how bad was it?" or how it compares to the modern system, but we must ask "what did the penitentiary accomplish?" The rehabilitation of inmates was clearly not accomplished, but it is apparent this was rarely anything but a secondary consideration.

The penitentiary was part and parcel of the capitalist enterprise.

Understanding the prison primarily as a humanitarian impulse obscures this reality, and causes us to miss key questions. Like the reformers he studies, McCoy also wishes to put an individualized face on the system's inmates, for only then can we appreciate the "historical effect of the modern penitentiary." Otherwise, prisoners are reduced to unsympathetic and ahistorical "others." 